\title{
Midcareer transition: Opportunities in work clothes*
}

\author{
D.J.W. Strümpfer \\ Graduate School of Business Administration, University of the Witwatersrand, Johannesburg
}

While the possibility of crises is not ignored, a generally optimistic view is presented. The subjective experience of and various styles of dealing with the midcareer transition are described in the context of the human life cycle. Various psychological and environmental antecedents are described to provide an understanding of the events that occur at midlife. Considerations on smoothing the transition are discussed, as well as aspects of the sequel to a successful transition.

S. Afr. J. Bus. Mgmt. 1984, 15: 85-95

Hoewel die moontlikheid van krisisse nie geïgnoreer word nie, word 'n algemeen optimistiese siening aangebied. Die subjektiewe ervaring en verskeie style in die hantering van die middelloopbaan-oorgang word in die konteks van die menslike lewensiklus beskryf. Verskeie psigologiese en omgewingsgebeure wat daaraan vooral gaan, word beskryf ten einde te begryp wat teen middelleeftyd gebeur. Optredes wat die oorgang mag vergemaklik word bespreek, asook aspekte van die nagevolge van 'n suksesvolle oorgang.

S.Afr. Tydskr. Bedryfsl. 1984, 15: $85-95$

- Expanded version of paper read at a symposium at Institute for Manpower Studies. P.U. for C.H.E., Vanderbijl Park, 9 June 1983
Nature, in denying us perennial youth, has at least invited us to become unselfish and noble.

George Santayana (1863 - 1952)

The developmental phase known as the midcareer transition has proved to be of considerable interest to people at higher occupational levels. The importance of an understanding of people at midlife becomes clear when one considers that most positions of power and leadership in work organizations, as well as in society at large, begin to go to people at about this age. Certainly such positions go to people who have traversed midlife successfully. Middle age is when people become the bearers of norms and become makers of momentous decisions. In business and industry this is the age of entry into top management.

Perhaps a good portion of the interest in this phase of life is explained by its other title, midcareer crisis. This label implies that midlife holds the potential of being problematic, with at least some people functioning suboptimally. If this is so, it is another reason why it is important to understand people at midlife: to find ways of enhancing effectiveness. This is a particularly important consideration in South Africa, on account of the limited high-level human resources.

The concept has but a short history. In 1965 an article by Elliot Jaques (1965:502 - 514) appeared in the somewhat obscure International Journal of Psychoanalysis, under the title 'Death and the Mid-life Crisis'. He wrote that he first became aware of this period as a critical stage in development when he noticed a marked tendency towards crisis in the creative work of great men in their middle and late thirties, a point he went on to illustrate with examples from the lives of creative geniuses like Michelangelo, Dante, Shakespeare, Goethe, Mozart and Gauguin. The article also contained a lengthy case history of a patient in psychoanalysis. Jaques then described his conception of the midlife crisis in some detail, but in terminology only fit for psychiatric consumption.

The amazing aspect of this article is that it has had such social impact. By now the concept which Jaques introduced there, has not only become a buzz-word in psychological and management circles, but part of the language of any reasonably intelligent person on the street. A surprisingly large collection of literature has also built up around the concept.

Some of this literature describes the experiences involved as really of crisis proportions, in view of the amount of upheaval and distress involved, or even the threat of catastrophe. Some authors view the crisis the way Chinese ideograms define them: not as failures, but as dangerous opportunities' (Davis, 1981:118-130) for personal development, 
i.e., as a combination of increased vulnerability and heightened potential (Erikson, 1978). Still others prefer the more muted terminology of midlife 'transition' (Levinson, 1978) in order to emphasize that it is only one of the periods of overlap between a sequence of major eras in the human life cycle. There are also authors who go so far as to say that: 'To the extent that the phrase is given uncritical acceptance, the midlife crisis is a myth' (Lawrence, 1980:35 - 49) especially since there is often an implication that it is something which occurs universally.

The overall orientation of this article is to convey the attitude reflected in the title, derived from a saying by the American industrialist, Henry J. Kaiser (1882-1967): 'Problems are only opportunities in work clothes'.

Below follows, first, a brief outline of the human life cycle in general. Then follows a description of the midlife or midcareer transition in context. A description of the antecedents of the midlife transition will follow, first the psychological, then the environmental antecendents. Some thoughts on making the transition smoother will come after that. By way of conclusion, will follow a description of what comes after a successful transition - almost as a matter of providing an enticing goal.

\section{The human life cycle}

Students of adult development, like Levinson et al.(1978) and Gould, described the full biosocial life cycle as a process or a journey, from a starting point (birth) to a termination point (death). Erikson (1978) wrote that his students nicknamed his course on this topic 'From Womb to Tomb' or 'From Bust to Dust'! Within the cycle there are a series of stages, eras or seasons, each with a distinctive character. Fairly specific ages are often mentioned for each stage, but this does not mean 'that a bell rings at precisely the same point for everyone, demarcating the eras as though they were rounds in a boxing match'. (Levinson et al., 1978). They represent average or modal ages, with a range of variation around the average. Between the stable eras there are also periods of overlap, or periods of transition, since the move from one to the other is neither brief nor simple. Figure 1 presents a condensation of Levinson's description. (A concise overview of work in this area can be found in Schein, 1978.)

Vocational psychologists too, have described life stages related to work and career (for a summary, see Schein, 1978). Hall and Nougaim (see Hall, 1976) identified the stages of Prework (0-25), Establishment (25-30), Advancement (30-45), Maintenance (45-65) and Retirement (over 65). Dalton, Thompson and Price (1977:19-42) described a useful model of four stages of professional careers. During Stage I the primary relationship is that of apprentice and the major psychological issue that of dependence; during Stage II these are the relationship with colleagues and the issue of independence; during Stage III they are the mentor relationship and assuming responsibility for others; while during Stage IV these become the sponsor relationship and the issue of exercising power. The four stages were not fully related to an age progression; neither did the authors see a need to include a midcareer transition period, since they described the possibility of reverting to an earlier stage, and then back to one of the later stages.

\section{The midcareer transition}

When and whom?

Authors vary somewhat in the ages they use to mark the midlife

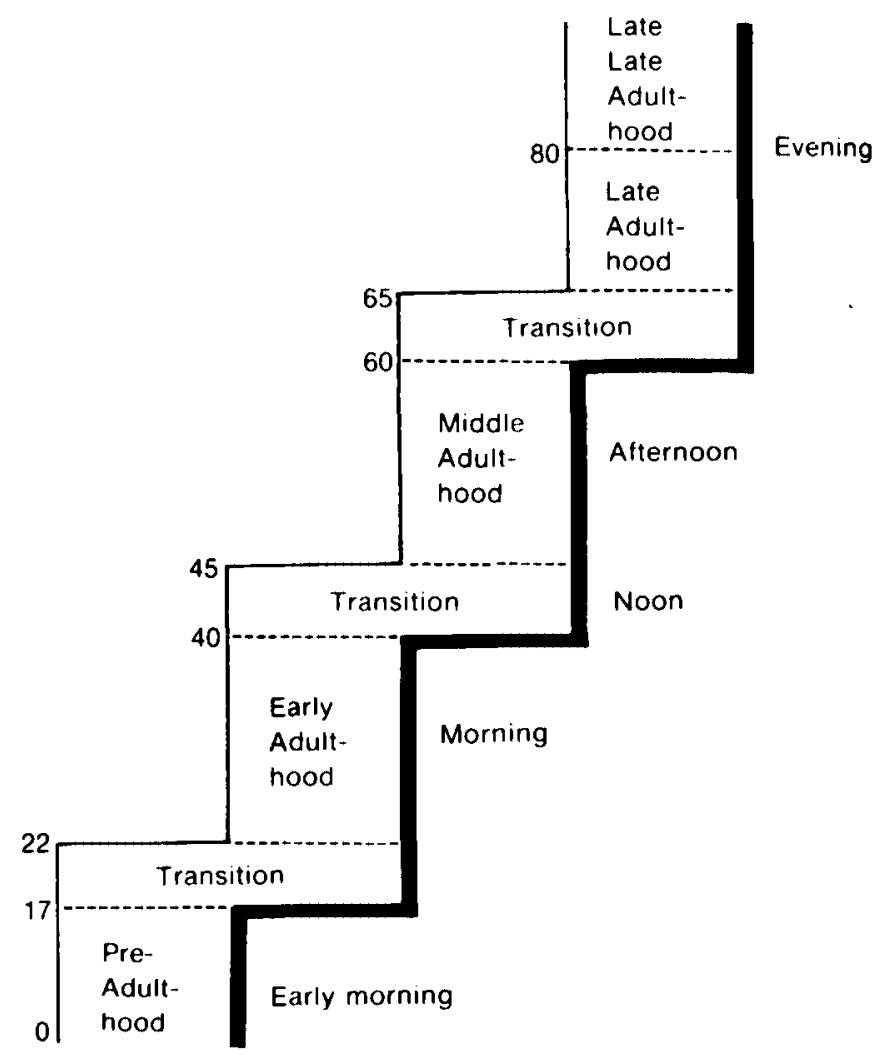

Figure 1 Stage in the human life cycle (adapted from Levinson, et al. 1978)

transition but for males the 35 to 45 decade embraces the range of ages that are usually mentioned. (The midpoint at $\mathbf{4 0}$ reminds one of the middle-aged patient whose doctor said he would give him something to fortify him, to which he replied: 'No Doc, I need something to twentify me!')

In the case of females, it is difficult to generalize about the adult part of the life cycle, since it is influenced by a number of variables. Her own attitudes and those of significant others around her from childhood onwards, but particularly that of her husband if she is married, will determine how ambitious she feels about her role as worker outside home, how traditional she feels about her role as wife and mother, but then too the degree of conflict between these. Consequently, much of what will be described below may fit only the unmarried career woman (Gould, 1978) and to a lesser extent the married but childless career woman. Another factor that makes for a difference from what is typical for males, is that a very large percentage of women interrupt their working careers before they reach the age of about 25 for a career of motherhood. Some of them return to the world of work about ten years later, which could be viewed as part of their midcareer transition; by the time they reach biological midlife, their second working careers may be just well under way. It is thus necessary to look carefully at the situation of an individual woman to determine which career and the middle of what one is talking about. By and large, the literature on this general topic is orientated towards male careers and so, I am afraid, will this article be. (For reviews of the literature on female careers, with local emphases, see Kellerman, 1983 and van Rooyen, 1981.)

Unfortunately what will be said below, also applies mainly to people in the higher echelons of organization and in higher socio-economic positions.

From the inside, doubt and despair ...

Most descriptions of the midlife transition emphasize that it 
is a period of reflection and existential questioning, with questions like the following:

- What have I done with my life?

- Where am I now?

- Is what I am the only way for me to be?

- What do I really get from and give to my wife? My children? Friends? Community? Work?

- What is it that I truly want for myself and others?

There is also contemplation of the years ahead:

- What am I going to do with what is left of my life?

- What do I still want to accomplish?

- How much time do I have left for all of that?

There may be a strong realization that one has reached the noon of life. When one looks back, it may be with disappointment and despair at how little has been accomplished. When one looks ahead it is then likely to be with the realization that only a little more can be accomplished because life is finite. At the same time, there may be a deep yearning for a life in which one's 'real' (but only vaguely defined) aspirations, dreams, desires and values can be realized.

The pivotal point of Jaques' seminal description of the midlife crisis was the awareness of persenal death. The person can hardly ignore the fact that (s)he has stopped growing up and is now beginning to grow old. 'The paradox is that of entering the prime of life, the stage of fulfilment, but at the same time the prime and fulfilment are dated. Death lies beyond' (Jacques, 1965:506). By way of illustration, Jaques quoted the poignant words of a patient:

Up till now . . . life has seemed an endless upward slope, with nothing but the distant horizon in view. Now suddenly I seem to have reached the crest of the hill, and there stretching ahead is the downward slope with the end of the road in sight - far enough away it's true - but there is death observably present at the end (Jacques, 1965:506).

To Jaques and other psychiatrists or psychologists whose primary concern it is to describe psychological changes within the individual, the midlife crisis tends to be characterized by a mood of despair: 'It is essentially a period of purgatory of anguish and depression' (Jacques, 1965:152).

\section{... But not necessarily always}

Jaques' views have influenced many other authors to look for the elements of doubt and despair, but these are by no means universally present. A more balanced presentation was given by another psychoanalytically orientated writer, Kets de Vries (1978), who described four main styles of dealing with the midlife transition. He described a $2 \times 2$ matrix, using an activity-passivity dimension to describe a person's orientation to the external world, and a realism-distortion dimension to describe the degree of reality with which the individual perceives and interprets her/his environment. Figure 2 presents this classification. Kets de Vries emphasized that these are 'ideal types for purposes of classification' and added that simultaneous manifestation of more than one style by the same individual is not uncommon. Nevertheless, in recognizing a greater variety of coping, his description seems more realistic than Jaques' picture of unmitigated despair.

Depressive style: In order to continue from Jaques' description of midlife crisis, one can start at the bottom right-hand quadrant of Figure 2. It combines a mode of passivity and lack of dynamism with an unrealistic, distorted view of the external world. Individuals who show this style feel that all has been in vain, and that there is little reason for continued

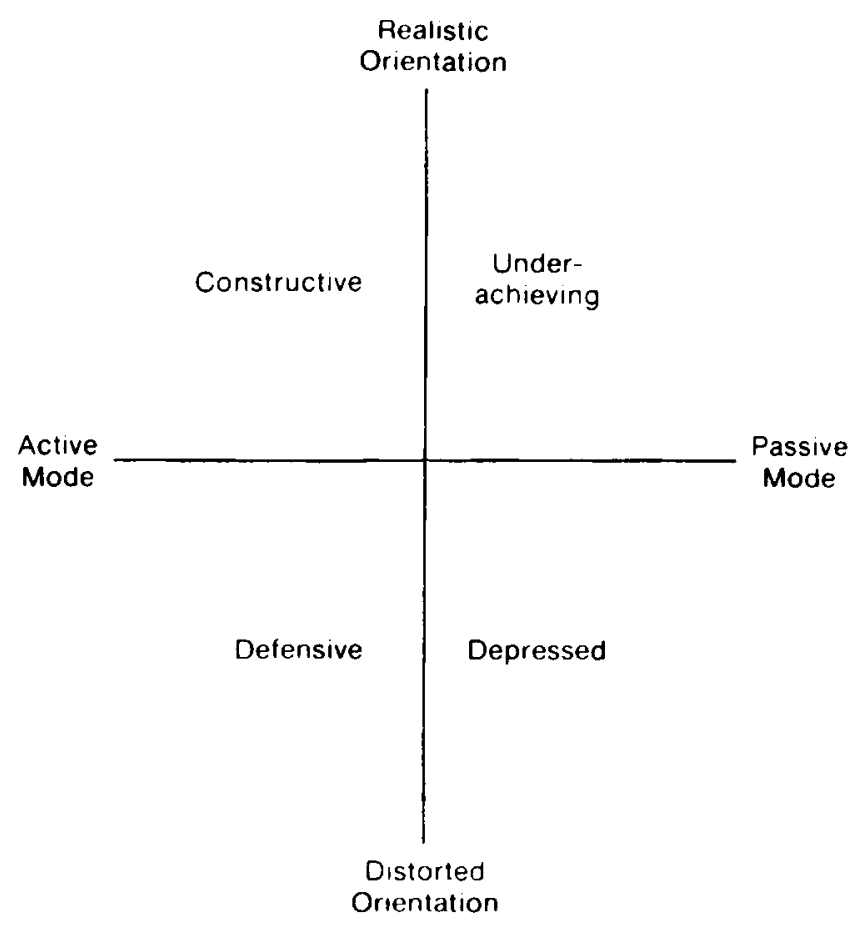

Figure 2 Four main styles of dealing with midlife transition (Adapted from Kets de Vries 1978)

existence. They also lack confidence for new departures, continued learning and future development.

Defensive style: The combination of a distorted view of reality with the active mode makes for at lest three defensive stances. The first, scapegoating, can be seen where the person is unwilling or unable to accept that his/her unrealistic aspirations are not going to be achieved, is angry about it all, and then blames others for his/her situation. The younger generation, who constitute real threats through their new skills and new techniques, form a ready target for anger, bitterness, jealousy, and even abuse of power. Denial, the second, takes the form of refusal to admit to inability to reach the unrealistic goals. A denier may escape into attempts to remain young, e.g., a concern over health, fitness and appearance, or sexual promiscuity in order to prove youth and potency; alcoholism or increased religious concern may also mask denial. Compulsive activity may be another defense, where the individual engages in frantic work activity in an attempt to attain the desired but elusive goals. Kets de Vries quotes a German expression, 'Torschluss-panik', the panic over the gates that are closing, to describe them. Of course, the panicky hyperactivity is likely to lead to only partial success, eventually accompanied by a sense of weariness and joylessness.

Underachieving style: It is also possible to combine the ability to face reality with passivity, without high aspirations and consequently without a strong need to restructure one's life. Such persons do not 'rock the boat', do not experience turmoil, maintain a low profile and are candidates for obsolescence; yet they maintain 'a great sense of realism and personal insight into their own strengths and weaknesses' (Kets de Vries, 1978). They also experience little, if any, distress and their midcareer phase is likely to pass without trauma or drama.

Constructive style: Lastly, it is possible to develop a heightened level of reflection and contemplation, based on increasingly mature insights. This constitutes an ability to face reality, to engage in realistic stock taking. But here it is combined with 
an active approach which leads to attempts to restructure one's life on the basis of new information and new understanding. If there are feelings of disappointment, these can be worked through with a minimum of bitterness while modifying one's original aspirations in terms of the feedback from one's past performance. The achievements may, however, also be in line with the earlier aspirations, leading to a sense of satisfaction and fulfilment, and to enhanced selfesteem. Even though the person realizes that the character of his/her life is changing, the transition is, in this case, a rather peaceful event.

When a person goes the route of modifying her/his aspirations, followed by constructive change, it could lead to a change of career.

As the years pass, most people - regardless of their professions or skills - find their jobs or careers less interesting, stimulating, or rewarding. By midlife, many feel the need for new and greener occupational fields. They yearn for opportunities to reassert their independence and maturity and to express the needs and use the talents of a different stage of life (Levinson, 1983:

123.)

For many executives, experienced in managing a department in a large organization, going into business on their own is an attractive second career. Various kinds of small-business opportunities may be open due to the person's training and experience but sometimes it may be an even more radical, highrisk change of direction, precisely because the person feels a need for unusual challenge. The rise in franchised business enterprises and the mushrooming field of computer services (Constandse, 1972: 129-133) are American trends that are opening entrepreneurial opportunities in this country too.

A career change may necessitate additional training, as a matter of continuing education, re-orientating education (like engineers or accountants who obtain MBAs to facilitate entry into general management), or even a completely new education.

Of course, organizations also provide opportunities for career change, e.g. transfers to other departments within the same company, to other companies within the same group, or from professional, scientific or technical posts into general management. Similarly, society provides opportunities for (at least partial) career changes or career enrichment, like positions of leadership or service in the affairs of church, education, welfare or local government - areas where there is a constant need for the talents of experienced business or professional people.

\section{Antecedents of the midcareer transtilon}

\section{Psychological antecedents}

In writing on the midlife crisis, there is the danger of viewing it as an isolated segment of the life span. It is not nearly as common a mistake as Lawrence (1980) would have her readers believe in her attempt at destroying 'the myth of the midlife crisis'; just about every author on this topic who is worth reading makes the point explicitly or implicitly. Yet she states the case so succinctly that it is worth quoting her:

... many experiences in life are sequentially dependent on one another and continuous throughout the life span. Each new experience is not isolated but is built on the total body of experience to which the individual already has access . . . . lives cannot be understood merely by photographing them at a particular moment. Thus like any other event, a midlife crisis must be understood within the cumulative experience of the individual (Lawrence, 1980:38).
The point need however, not be belaboured when one uses the concept of midlife transition.

In trying to understand the psycho-logical appearance of the midlife transition, one therefore has, at the very minimum, to look at the preceding era of early adulthood (see Figure 1). Hall referred to it as a period of advancement, while Levinson et al. (1978) described two substages of 'settling down' and 'becoming one's own man'. Such descriptive phrases reflect the high degree of activity that is typical of this period: it is probably the busiest time of one's adult life.

In the thinking of Levinson et al. (1978), there are two major tasks during this period. The first is to establish one's niche in society.

A man needs a sufficiently ordered, stable life. It is a time to deepen his roots, to anchor his life more firmly in family, occupation and community. He takes a greater sense of pride in knowing who he is, having his own home base, developing competence in a chosen craft, belonging, being a valued member of a valued collective entity (Levinson et al. 1978:140).

The second task is to work at advancement. It is a matter of 'planning, striving to succeed, moving onward and upward, progressing along a timetable' (Levinson et al. 1978:140). The goals of advancement may be 'wealth, power, prestige, recognition, scientific or esthetic achievement, particular forms of family and community life' (Levinson et al. 1978:140).

These authors described the later stage of early adulthood in terms of a distinctive striving to be more independent and self-sufficient, as 'Becoming One's Own Man'. The individual wants 'to become a senior member of his enterprise, to speak more clearly with his own voice, to have a greater measure of authority' (Levinson et al. 1978:144). Dalton et al. (1977) described something quite similar as the second of their four career stages, where the central activity is to become an independent contributor. In doing so, (s)he develops a sense of competence but also enhances his/her visibility in the organization. In terms of relationships, this means moving up from apprentice to colleague.

Whether by design or accident I do not know, but Levinson's acronym for 'Becoming One's Own Man', BOOM, also contributes to understanding the tenor or this period. Two meanings of 'boom' seem applicable: 'a deep, loud, resonant sound', and 'sudden rush of activity or development (as opposed to slump)'. It is a period of noisy hustle and bustle which the above, rather cerebral descriptions do not reflect well. Some people may 'put in ten or fifteen hours a day, six days a week, hoping to impress their bosses with their devotion to duty and assuring themselves and their families that "this is necessary if I want to grow" ' (Souerwine, 1977:56). It is, however, not only a matter of quantity but also a striving for quality, the belief that 'all things come to those who perform well', and 'Whatever you do, always do your best' (Souerwine, 1977:57 - 58). Bartolomé (1983:67 - 74) spoke of 'prisoners of success', who simply fall in love with the job and the rewards it brings.

Heavy financial demands are often part of the striving for advancement at this stage: buying a home, moving to a larger home with a better address (perhaps more than once), home improvements and extensions, orthodontic treatment for the children, et cetera, on and on.

In this phase some people show what has been labelled 'the virtue of apartheid': 'It's important to keep your home life and work life separated' (Souerwine, 1977:59). In a deeper psychological vein, Davis and Gould (1981) described an 
addiction to work that goes beyond simple hard work, in that it is a defense against intimacy; frantic activity then becomes a way to deal with anxiety about the absence of deep emotional attachments, especially in married life. In this connection, Bartolomé (1983) referred to the currently popular label for such persons, 'workaholic'; in its connotation rooted in 'alcoholism', it implies escape or avoidance of problems through a drug, in this case, work. He commented that despite the similar consequences (estranged family, impaired health), society (certainly business organizations) condemns alcoholism but condones and even applauds workaholism.

Not everyone remains unaware of the implications of the frenetic work for marriage and family - some only postpone doing something about the feelings of loneliness and emptiness which they experience from time to time. Writing about the 'Mañana' attitude, Bartolomé described how men and women may keep saying to themselves that they will recapture at some later stage what they are giving up while they are making sacrifices for the sake of their careers.

This, of course, is impossible. The experience a person misses today can't be had tomorrow . . . . We cannot recover the relationship that we didn't have with our children when they were young. Many parents discover to their regret that they have missed their children's childhood .... The parent who tries suddenly to establish a friendship with his or her 16-year-old son or daughter after years of neglect often learns that it is too late (Bartolomé, 1983:71).

In this connection it is worth recalling that Erikson (1963) described three stages of adult development, the first of which lasts from about age twenty-one to age thirty-five and has as its central theme the struggle for intimacy. He also made it clear that if the tasks of this stage are not accomplished, the alternative is aloneness and isolation, with all the ensuing pain and anxiety. For business executives this may, however, be an occupational hazard: "concentrating so thoroughly on the challenge of bottom-line effectiveness that they avoid developing the human side of their personalities" (Davis \& Gould et al. 1981:128).

At an even deeper psychological level, an addiction to work may also reflect anxiety about 'the ugliest fact of life, one's own death' (Davis, et al. 1981: 126) Men, especially, may see work sucoess as the route to immunity from death (Gould, 1978).

Work organizations may stoke these internal fires even more, by placing the individual on a 'fast track', by moving him/her through a wide variety of challenging jobs and constantly shifting him/her on to 'new learning curves'. There is also rapid promotion throughout the early portion of the career. Every move is planned to stimulate, develop and expand the individual's potential. But, as the letters 'IBM' are jokingly interpreted in Germany, it means 'Immer bis Mittelnacht' always having to work till midnight!

The main thrust of my argument here is that a person who, for whatever reason, is constantly at work, who may even be said to be addicted to work, simply does not have the time or energy to reflect and contemplate properly on what (s)he is doing, what the value and meaning of her/his work or contribution is, or where it is going to lead some time in an unthought of future. On the other hand, much anguish could be avoided if some existential questioning could be done along the way, and not be postponed until it reaches a crisis point at midcareer, when it simply forces itself on the individual.

Similarly, if the individual could allow her/himself to invest in intimate relationships, much of the sense of loneliness and isolation could also be spared. In Erikson's (1963) terms, the central task of roughly the forties is 'generativity', i.e., assuming responsibility for the development of new generations of adults. However, it can only follow after successful accomplishment of the tasks of intimacy during the preceding stage; thus, failure at the intimacy tasks does not only lead to isolation in the short run, but also to the stunting effect of stagnation, as the alternative to generativity.

In short, for a large number of people the frantic activity of the period that precedes the midcareer transition is what causes the transition to be catastrophic.

\section{Environmental antecedents}

Psychological theories about adult development tend to overemphasize psychodynamic changes within the individual, sometimes almost as if (to rephrase John Donne) 'man is an island, entire of it self'. There is often almost an implication, too, of weakness for which the individual has to carry the blame. Although such explanations tend to have a very dramatic flavour, it is unrealistic to ignore more mundane influences from the individual's environment. I shall mention a number of these external, environmental factors which should be considered in trying to understand the midcareer transition.

\section{Family situation}

At midcareer people experience a variety of situations in their families that are unique to this phase of life but which certainly do not ease the transition.

The first of these is the person's position in the sequence of generations - between the family of origin (the parents') and the families of his/her children, but still in the midst of his/her own family too. By this stage there is the beginning of a reversal of roles, where the middle-aged person has to take on 'parental' responsibilities for parents, uncles and aunts - the generation of the elderly who, in general, begin to look to him/her for care and leadership (Levinson, 1978; Gould, 1978).

It may, however, go deeper than this. In his description of one's own awareness of personal mortality, Jaques described the person's sense of the agedness of parents (or even the reality of either or both parents being deceased), coupled with the maturing of children into adults (perhaps having children of their own). This situation contributes strongly to the individual's sense of aging, that it is her/his turn next to grow old and die. As Jaques pointed out, nobody now stands between the individual and the grave; in fact, (s)he had now become the barrier between her/his children and their perception of death.

By this stage, a man and a woman experience sharply changing relationships with their children. If they started a family in their twenties, the children will be in or near adolescence by the parents' forties. Parent-child relationships are particularly strained during this phase of the children's development, with the youngsters asserting their independence and resenting interference and 'paternalism', yet expecting and demanding protection, caring and security - both emotional and material. (Some wag has said that at first the parents answer the questions but adolescence is when the children question the answers!) Some or all of the children are also leaving the home by this stage, leaving the parents with their 'empty nest syndrome'. Disappointments with children may also add to self-doubt and questioning.

The relationship between husband and wife may be strained, undergoing changes, or even breaking up. When the parents 
suddenly have only each other, weaknesses which family responsibilities helped to keep submerged in the past, have to be confronted. At this stage the woman's role could undergo radical changes. If her time is no longer taken up with the children, equally to her husband's devoting most of his time to his work, the emptiness and boredom may place severe strain on the marriage (or surface old strains). At or before this stage, women quite commonly return to employment, as a replacement activity, thus introducing the strains common to a dualcareer family.

A variety of physical factors may add to the strains. Both are changing in physical appearance as they are losing their youth: wrinkles appear; the woman may have lost her slenderness and the bloom of her skin; the man may be balding and may begin to show a paunch ('Middle age is when broad minds and narrow waists change places'). The wife goes into her menopause (Archie Bunker called it 'mental pause'). Either or both may experience breakdown in health. As a result of such factors or as a result of failure over the years to invest in the relationship, personal interest and warmth may be gone, and sexual problems may appear. For both sexes, self-esteem may be tied in with sexuality - for the woman her attractiveness and for the man his prowess - so that such realizations and frustrations may be deeply anxiety-provoking. (It is not every one who can show the mature acceptance of Archie Bunker, to quote that bigoted sage once more, when he told his wife in bed: 'Let's not start something I can't finish!') Either or both may go outside the marriage in search of reassurance, renewal or affirmation. Even though it is never easy, it is, however, also possible to gain reassurance, renewal and affirmation within the marriage, through extensive renegotiation and restructuring of the relationship (Sherwood \& Glidewell, 1975). As Gould has pointed out:

'In a strong, flexible marriage in which all issues are negotiated through dialogue, both partners can continue their necessary growth and change - but they must expect turmoil, confusion, arguments, blame and plenty of anxiety' (Gould, 1978:279).

Changes in the material circumstances of the family may contribute to the complexity of the transition too (Isaacson, 1981). There may be a need to accept responsibility for dependent parents. Financial responsibilities may increase as a result of a desire to live better, to provide better schooling for the children (e.g., private schools are expensive), or of having children at university. Financial problems may be compounded when a husband has to support a wife and children from a previous marriage. On the other hand, paying off a mortgage or having the last child complete studies, may reduce the financial pressures. In turn, such an event may raise the question: 'Do I really need to keep on doing this?' If the wife returns to employment, she may "reduce the "locked-in" pressure previously felt by the sole breadwinner, and may increase the opportunity for modest or major risk taking, thus leading to renewed efforts to realign life values and work' (Isaacson, 1981:327). In fact, the wife's 'participation in fulfilling and satisfying work may provide the model that causes the mate to realize that he, too, could be involved in activities that are challenging and actualizing instead of only income producing' (Isaacson, 1981).

A sad comment on the Sruth African system of joint taxation of married couples is also due here. There is the likelihood that taxation on the combined incomes may be so high as to penalize especially the wife's attempts at self-actualization through work at this stage. It is especially a predicament in the case of highly-trained women in high-level occupations where womanpower is a very valuable resource. Alternatively, with other financial demands reduced, it could encourage the husband to seek less remunerative employment; but in the process he would also remove his skills and experience from a level of employment where these resources are in desperately short supply.

\section{IIIness and death}

Throughout life, a person's peer group constitutes an important frame of reference. Consequently, serious illness and death among peers cannot be ignored as a factor in a person's concern about mortality and the meaning of her/his life. While illness and death do occur before midlife, they tend to be dramatic exceptions which a person can ignore or rationalize away. By midlife, however, the incidences increase to a point where they force themselves to one's attention.

Among South African males the mortality rate for coronary heart disease, for instance, is only 23 per 100000 between the ages of 23 and 34, but increases to 163 between 35 and 44 , to 492 between 45 and 54 , and to 1118 between 55 and 64 (Wyndham, 1978) - rates hard not to become aware of. Accident proneness peaks in the 35 - to 45 -year-old group, and there is a sharp increase in the suicide rate in early middle age, particularly for women (Kets de Vries, 1978).

What figures like these mean, is that few people pass midlife without experiencing deeply the concern for peers who have suffered serious illness or the pain of loss through death. The older people, like parents and other relatives, family friends, older colleagues, and even public figures, all of whom had simply always been reliably there, begin to suffer and die at an alarming rate when one reaches midlife. But then the conclusion becomes unavoidable: 'If they can die, I can die too'. Gould was of the opinion that:

Men seem to be more surprised at the fact of mortality than women. They often react to the news of a death as if someone has played a dirty trick on them. In midlife they can become preoccupied with the topic of death for long periods of time, during which the deaths of friends or relatives around their age scare the hell out of them. They lose confidence in themselves and confuse their awareness of death with their situation at work (Gould, 1978:229 - 230).

Of course, if the person actually experiences a heart attack or some other life-threatening illness, it destroys her/his illusion of invulnerability, or even the illusion of immortality. That shock, in turn, is likely to require new alignments of work, of relationships and of values. Yet, even such personal illness remains an external factor, 'an act of God', which, if it happens at midlife, contributes to the complexities of the transition.

According to Gould (1978:246), women - in contrast to men - 'feel an increased mandate to act on their own behalf' when they face the realization of their own mortality. In Western societies the majority of women who reach midlife now, have been brought up with an 'archaic version of feminity', which makes them assume falsely that, 'It is impossible to live without a protector in life'. The implication is also that a woman can exercise power only through a man. Gould (1978:246-266) described colourfully the diverse processes through which women can come to take back the power. What seems most important is that if and when women shed the 'protector myth' they are freed to an expansion of their own personalities, to experience a broader range of social contacts, as well as to appreciate work as work. 
Work situation

One of the serious frustrations and disappointments in the career of an executive which is likely to arise by mid-life (if not sooner) is that of a career plateau. Quite apart from personal factors, an individual may find him/herself 'plateaued' (a neologism that has recently made its appearance) as a result of the ever-narrowing hierarchy of most organizations, which slowly but surely reduces the number of opportunities for promotion to higher levels of decision-making authority and power. The majority of managers must come to some form of halt in their careers and the crunch becomes more likely by midcareer.

In South Africa people may experience a special form of the plateau problem. As a consequence of the shortage in highlevel human resources, there are exceptional opportunities for early promotion. However, if the individual is not as able as (s)he or the superiors had assumed, (s)he may be promoted out of competence, leading to a painful sense of entrapment by midcareer.

Unfortunately, organizations tend to be reluctant to face a person's attainment of a plateau (at least as long as things are going well for the organization). Such failures are usually disguised through ambiguous organizational arrangements, such as being promoted 'laterally' or being 'kicked upstairs' (Kets de Vries, 1978). However, the person concerned may, again, experience this treatment as entrapment. 'Frustration, alienation, and the loss of purpose may manifest in burnout, withdrawal, or anger - behavior extremes that may potentially disrupt the work and the nonwork relationships of employees. Turnover may occur as often on the basis of change for change's sake, as on a perception of greater opportunities elsewhere' (Dawson, 1983:78-81). One can also imagine the effect on the encumbent's self-esteem: 'When the world seems to validate a person's self-doubts with the label of loser, the mid-life transition abruptly turns into a mid-life crisis' (Davis et al. 1981:122).

It is when things are not going well in the organization that those entrapped on a plateau find themselves in serious trouble. In the event of a recession, or when it is necessary to run a lean and hungry company in a competitive market place, or after a merger or a take-over, management is likely to prune staff to get rid of dead wood (Constandse, 1972).

Fast-track programmes should be mentioned again in connection with career plateaux. If an individual has had a fastpaced, continually challenging early career, which peters out by the middle to late thirties, a 'timetable of expectations' (Kets de Vries, 1978:50) is overturned, which is likely to aggravate the sense of entrapment.

Obsolescence is another job-related factor which could increase progressively by midcareer. At an accelerating rate, the knowledge explosion and rapid technological change render knowledge, know-how and skills - which may have been at the leading edge only a few years before - outmoded or downright valueless. To mention some examples:

- One estimate has it that, 'Written information presently accumulates at the rate of 500,000 pages per minute. At that rate, we accumulate a stack of new material 187.5 feet high every minute' (HSSE Newsletter, 1983).

- By now containerization is old hat, but only a few years ago it was costing people their traditional jobs and demanding a total rethink of materials handling.

- Until quite recently robots only populated comic strips and science-fiction stories; today robotics is a whole field of specialization in industrial engineering and management (e.g., McConkey \& Barrett, 1982) and even in personnel management and industrial relations. (Argote, Goodman \& Schkade, 1983:31-41; Saga, 1983:21).

- Computerization, in general, has made numerous skills obsolete while demanding new approaches, even new ways of thinking. In an article titled, 'Dealing with terminal phobia', it was commented that, 'In the office of the future, some executives prefer the past' (Taylor, 1982:74).

- Job changes are becoming more common due to transience and turbulence in the world of work. Time magazine recently quoted a prediction that, on the average, Americans will now be changing jobs four times during their working careers (Alexander, 1983:68 - 76). However, massive needs for retraining and readjustment are among the consequences.

In industry technological obsolescence may result in discontinuation of a product, development of new products, substitution of a process, mechanization, automation (perhaps robotled) of manual processes, or relocation of a process or of a plant; it may involve a single production process in a small plant, or it may involve a total industry (Isaacson, 1981). Whichever form it takes, it will leave people stranded, usually with traumatic demands for readjusment. Among professionals and knowledge workers the shifts are not so abrupt and observable but more steady and unceasing, demanding life-long continuing learning. Paraphrasing the Peter Principle, Houle (1980:103) wrote: 'Professionals rise to the level at which they no longer learn how to deal with the problems they confront'.

Obsolescence tends to be particularly painful when it is experienced in the context of the younger generation pushing the middle or older generations aside. Margaret Mead (1972) compared people living in the world of nuclear, computer and space technology to immigrants living as pioneers in a new country. Under such conditions the problem of the elders is that their thinking is bound to the past and that their skills for dealing with life in the old country are not only outmoded but may be dangerously maladaptive. The young, on the other hand, have known no other country, do not find the new one fearprovokingly foreign, and because they are at home in it they function quite effectively. This results in a role-reversal, the kind of situation Robert Frost described:

Now I am old my teachers are the young.

What can't be moulded must be cracked and sprung.

I strain at lessons fit to start a suture.

1 go to school to youth to learn the future (Lathem, 1969). (The younger generation emphasize the other side of the coin thinking that, in George Bernard Shaw's words 'It is all the young can do for the old, to shock them and keep them up to date'.)

Of course, not everyone who is exposed to new developments feels threatened to the same extent:

If the person experiences a sense of achievement in the attainment of his career aspirations, he makes a strong effort to stay abreast of current developments. If that sense of achievement is absent, and instead a sense of personal frustration and failure prevails, rapid obsolescence is often the consequence (Kets de Vries, 1978).

\section{Making for a smoother transition}

Neither the existence, nor the seriousness of problems like those described above can be denied. Yet one should be cautious of the attitude that people are helpless victims of an unavoidable series of events that is almost bound to crush them. It is possible to prevent crises. It is possible to view and experience 
the midlife transition as a phase of growth, with problems along the way that are 'opportunities in work clothes'. When a person is viewed as an 'origin' with an internal locus of control, and not as a 'pawn' at the mercy of outside forces, (De Charms, 1968) various ways of making for a smoother midcareer transition come to mind.

Education: In the first place, a certain amount of public education seems to the point. The available information about adult development can be used to plan a more effective life. If people are more aware of, and have a deeper insight into, what typically happens during various phases, they may just handle those phases a little better - on their own, in cooperation with their spouses, relatives and friends, in superior-subordinate relationships, even with the aid of a counsellor if need be. A manager as mentor could, for instance, counsel and guide a protégé to handle the settling-down and advancement of early adulthood in ways that will prevent a midcareer crisis.

The very knowledge that a phenomenon called 'the midcareer transition' exists, and to have a description of what is typically involved, can also help a person traverse it better. To be forewarned, may help her/him to be fore-armed. To know that one is not unique in experiencing self-doubt and turmoil, even when of crisis proportions, to know that the transition is experienced similarly by many others, to know that it has been studied, analysed and labelled - may come as both relief and encouragement. It may also make the individual more receptive to social support, and even to counselling, if the experience is viewed as legitimate because 'everyone else is having it too'. To know what may be beyond the transition may contribute further, by providing goals to live and strive for.

Career planning and counselling: Career planning, with or without the aid of a counsellor, is probably the most efficient way of divising an effective adulthood, especially planned transitions, as well as to prevent midcareer crises. Ideally, it should be an ongoing activity throughout a person's career and it should be timeous enough to enhance personal effectiveness at all stages. It should be proactive and preventive, rather than to be reserved reactively for instances of severe crisis only.

Successful career planning and development must be a process which accompanies each job change or role transition, beginning before the new role is undertaken to assure establishment of objectives and goals, and continuing through the adaptation period to facilitate the integration of the emerging subidentity (Bowen \& Hall, 1977:26).

A whole professional speciality has sprung up around career development and this is not the place for a review (see e.g., Hall, 1976, Schein, 1978; see Bowen \& Hall, 1977, for 'a primer for managers'). I shall only make a few general comments.

In the first place, the person him/herself has a strong responsibility to plan a career, to prevent obsolescence and to deal constructively with the midcareer transition when (s)he reaches that point. Self-help career planning - consisting of setting personal career objectives or personal planning, partly in collaboration with the spouse, family and friends - depends on the individual's willingness and capacity for self-direction. Executives often have considerable planning skills, which they use most successfully to the benefit of their organizations; it is then simply a matter of 'physician, heal thyself', in bringing such skills to bear on their personal affairs too.

By the time a person reaches midlife, it is unlikely that a superior can be of much use as a counsellor. By then, the men- tor relationship should have come to a natural end. 'A paternalistic involvement by a manager is not desirable, particularly since much of the struggle a person goes through at mid-life is to shed the effects of such controlling influences in his or her earlier life' (Davis, et al. 1981:129).

Managers should rather make professional counselling available. Companies increasingly use part-time psychologists, psychiatrists and social workers, or refer employees to helping professionals in private practice or to career development centres. An outside resource is usually preferable, since career and marital problems are often intertwined, with the latter clearly none of a company's business from the point of intervention. There is also the matter of confidentiality: to be effective the counsellor should be trusted fully and there should be no danger of highly personal information given to her $/ \mathrm{him}$ becoming part of the personnel record (Kets de Vries, 1978).

Three broad kinds of counsellor-client activities can be distinguished (Bowen \& Hall, 1977).

(a) The first is the testing approach where the counsellor administers aptitude, vocational interest and personality tests and feeds back data to the client, as a basis for decisions about his/her suitability for certain types of occupations.

(b) In the second, the clinical approach, the emphasis is on a process of quasi-psychotherapeutic interviewing to provide the required data. The orientation tends to be somewhat non-directive in order to help the client explore his/her own needs and values. Tests may sometimes be added as an adjunct to the process.

(c) Group strategies for career planning and career redirection have also been developed. Apart from being costeffective, they have unique advantages, such as an expanded supply of information on solutions or job opportunities, shared concerns and group support (even continuing after the workshop), opportunities to experiment with new behaviour in a safe situation, modelling behaviour on that of other participants, and development of social skills through role-playing of e.g., a job interview or interaction with a difficult superior.

By the time the individual is in early adulthood, various ways and means should be explored by the individual, by her/his superior in a mentorship capacity, and probably by her/his employing organization. The objective should be to attend to those psychological aspects of this phase of life which could cause problems at a later stage if they were to be neglected. Some of the problems were described above, as pscyhological antecedents of the midcareer transition. Schein (1978) provided a list of tasks specific to early adulthood which is worth considering.

Planning, counselling, and career development workshops during the midcareer transition itself should deal with at least the following specific tasks, also listed by Schein (1978:43 - 44):

(a) Becoming aware of one's occupational self-concept (or career anchor), which includes self-perceived talents and abilities, motives and needs, attitudes and values.

(b) Assessing the implications of the above components of the self-concept for one's future.

(c) Making specific choices about accepting the present or working for whatever future is visualized.

(d) Working out new accommodations with one's family around the specific choices made.

(e) Working out mentorship relationships with others.

Preventing obsolescence: The danger of obsolescence has to be considered seriously, both as a matter of prevention in the 
longer term and of short-term amelioration.

When it concerns technological change in industry, it is a matter of progressive personnel policy, that will allow for retraining and various ways of providing material and social support during periods of readjustment. Too often the readjustment process is marked by callous laying off of those considered redundant.

Even though more complex skills are involved in the case of managers, professionals and technicians, it may be easier to prevent obsolescence and plateauing at these levels. In some instances, it may require upgrading of skills or retraining for a new career in a related or even an unrelated field, over a relatively short period, just as in the case of industrial workers. In many instances, it is a matter of systematic lifespan learning, in formal and informal ways, as part of a planned career. Notwithstanding great emphasis on general training in many companies, it is only infrequently tied in with proactive career monitoring and the planning of career paths, in which responsibility is shared by the individual and the company.

Nevertheless, it is not uncommon for South African companies to encourage employees to improve their educational background, and hence both their job performance and potential, usually through re-imbursement of tuition fees and related expense upon successful completion of approved courses of study. At the lower educational levels the support may even be 'up front'. Arrangements of this kind ought to be part of the social policy of a company and it should be supported by active encouragement and reinforcement.

With a somewhat socialistic bias, Kets de Vries (1978) expressed the opinion that innovation in the area of continuing education tends to result from appropriate legislation. As an example, he mentioned Swedish legislation which gives employees the right to attend courses of their own choice at company expense after they have worked there for either six months or for at least twelve months out of the last two years. Another example is France, where an employer must pay employees for leaves of absence for the purpose of continuing vocational education after a minimum of two years of service if they had not been awarded a diploma or training certificate in the last three years.

In academia a sabbatical is a highly valued way of keeping up to date. This arrangement is becoming not so unheard of for executives in North America, to be spent on study, social service work or other enrichening experiences. Dods (1980), a member of a consulting company, described his own sabbatical as a case study - in detail that makes even an academic's mouth water! Job rotation and time-bound executive posts (comparable to e.g., those of some South African university administrators appointed from academic ranks for a set period of service) have also been described as part of career development programmes to counter obsolescence and to ease the midcareer passage (Kets de Vries, 1978).

One could argue in a moralistic vein in support of organizational programmes like those suggested above. However, the costs of such programmes are likely to be balanced out by the benefits of morale and commitment of a work force that does not feel exploited but recognized as consisting of individuals with personal needs. When it comes to the higher levels in the organization, it is inordinately expensive either to fire halfeffective managers or to maintain managers who have been promoted to the level of their incompetence - when there is the possibility that their abilities could have been upgraded, re-directed and revitalized. I want to reiterate that in a situation of desperate shortage of high-level human resources, the available resources of experienced managers at midcareer should be utilized optimally. In the end, preventing obsolescence only makes good financial sense.

\section{What comes after a successful transition}

If people have to go through experiences, it helps to have a picture of what may be beyond, in this case, during the socalled middle adulthood. If the midlife transition and its opportunities are taken, like Shakespeare's tide taken at the flood, it leads to greater competence and to a more fullyfunctioning life (which could well have been part of Shakespeare's idea of fortune!). He was also to the point when he said about the tide in the affairs of men that if 'Omitted, all the voyage of their life/Is bound in shallows and in miseries' (Shakespeare); but I shall refer to incompetence and stagnation only in passing.

In his originative article, Jaques described a change in the mode of work of the great men whose lives he had studied, which occurred at midlife and after. 'The creativity of the twenties and the early thirties tends to be a hot-from-the-fire creativity. It is intense and spontaneous, and comes out ready-made.' By contrast, he described the creativity of the late thirties and after as 'sculpted', with an externally worked-over quality. In his observation, the inspiration may come more slowly and there is a bigger step between inspiration and the finished product, as a result of 'further working over, modification, elaboration, sometimes for periods of years' (Jacques, 1965:504).

Dalton et al.(1977) described something akin to this change in mode of work, during the fourth stage of professional career development, when exercising power becomes the major psychological issue. At this stage, people move away from the details of the daily work and even away from guiding and supervising the people 'at the coal face'. They have to think at the level of formulating policy and of initiating and approving broad programmes. Therefore, at this stage they must learn to use conceptual skills and to think about what the organization will need beyond the period during which they will be personally involved. Thus they move to a higher niveau of service to their organizations.

Part of what Jaques described was also a mature acceptance that life and the world will go on. It is accompanied by a serenity which transcends imperfection:

One's work need no longer be experienced as perfect.

It can be worked and reworked, but it will be accepted

as having short-comings. The sculpting process can be carried on far enough so that the work is good enough. There is no need for obsessional attempts at perfection, because inevitable imperfection is no longer felt as bitter persecuting failure (Jacques, 1965:513).

Traversing the midcareer transition successfully also brings a change in relationships with younger people. In part, it is almost an acceptance that, 'If I am mortal, others will be around to continue.' At the same time when there is resignation to the fact that important things one would have longed to accomplish or would have liked to possess will not come about, there is an increased sense of the continuity of human life (Levinson, 1983). But this tends to be accompanied, too, by deeper insight into the lives of others and perhaps a deeper capacity for love and affection. It can also serve to alleviate the feeling that the relationship between the generations is that of adversaries.

Such inner changes could lead to sincere attempts to assist those who have to come after in getting ready. As indicated 
before, Erikson (1963) called this the stage of generativity vs. stagnation. Generativity flows from a growing awareness of the continuity and flow of generations. It is the concern in establishing, counselling and guiding the next generation, in caring for individual and even institutions, in ways not done earlier on. It starts in the latter part of the midcareer transition and may continue throughout middle adulthood (see Figure 1).

The most significant organizational role in this phase of life is that of being a mentor. The term comes from Greek mythology: When Ulysses went on his ten-year odvssey, he entrusted the care of his son, Telemachus, to his friend, Mentor. Mentorship is a matter of counselling with caring, compassion, concern and generosity, of listening to hear, not ideas only, but feelings too. The mentor should not be a parent figure; rather (s)he is a transitional figure: 'The mentor represents a mixture of parent and peer; he must be both and not purely either one' (Levinson, 1978:99). What is more, 'He can keep what is youthful in himself, get in touch with both the Young and the Old in others, and use his middle age to enrich his relationships with the younger and older generations' (Levinson, 1978:253). Mentoring is, in part, an altruistic activity, of doing something for some one else. Yet it is also selfrejuvenating. By maintaining the connection between youth and the youthful in him/herself, the individual is also doing something for him/herself; by making productive use of his/her own knowledge and skill gained by developing into middle age, (s)he is also learning further in ways not otherwise possible (Levinson, 1978). Mentoring thus is a matter of facilitating growth in others, as well as of growing oneself.

Although mentorship typically occurs between senior and junior colleagues, it may occur in informal settings too, between friends, neighbours or relatives.

Mentoring is one of the situations where females are organizationally at a disadvantage, compared to males. Women receive less mentoring than men, whether from male or female mentors (Levinson, 1978; The Woodlands Group, 1980). The intimacy of the mentor-protégé relationship discourages male mentors from being a mentor to a woman, and vice versa, due to social pressures, doubts about motives, rumours, or even the realities of attraction. Since there are so few women in the world of work to serve as mentors, and since these few have to fight for survival in a male-dominated environment, female mentors for younger females are even scarcer. If a female mentor is available, she need not have female protégés only; experiences in at least the academic world certainly support the opinion of Levinson et al., that: 'A relationship with a fernale mentor can be an enormously valuable experience for a young man' (Levinson, 1978:98).

Mentorship is the concept that is usually emphasized in this context. As was indicated earlier on, Dalton et al., mentioned sponsorship as a related activity, at a still later stage of career development. The sponsor is in a position to advance a protégé's career on account of his/her position of power. It is less of a developmental task and it is also exercised on behalf of people who have advanced further in their own careers (See also The Woodlands Group, 1980).

Both kinds of change described above, in mode of work and in relationships, hold the promise of immense fulfilment and gratification. Yet these changes do not occur magically. They are the outcome of hard developmental work and of investment of oneself in the lives of others - of working at developmental tasks throughout one's life.

Naturally, there are wide differences in the degree to which people succeed in achieving such self-actualization. The alternative to the change in the mode of work may be that decline starts at an early stage, with work characterized increasingly by obsolescence and by the work becoming sadly oppressive and humiliating. The alternative to generativity is stagnation, not growing, being static, drying up, being bogged down in a life full of joyless obligations - living in the shadow of death (Levinson, 1978). It is of such people that Lord Byron wrote: There is an order

Of mortals on the earth, who do become

Old in their youth, and die ere middle age.

Between the extremes are many degrees of competence and fulfilment. What is, however, important is that the heights are attainable.

Notwithstanding one's sincerest optimism, an earlier comment needs some elaboration at this point. For better or for worse, optimal functioning is not altogether a matter of internal locus of control, personal commitment or personal responsibility. In 'making it' one is, to a large extent, also dependent upon the availability of social resources, particularly support from one's spouse, children, peers, subordinates and superiors, including mentors and even sponsors. Fortunate economic, social and political circumstances also contribute largely. For instance, much of what was described above is not even attainable as a mirage for the vast majority of Black agricultural, industrial or domestic workers in this country. It was for that reason that I said, almost in passing, that what was described in this article applies mainly to people in higher socio-economic positions and the higher occupations in organizations.

\section{Meshing company and individual needs}

By way of conclusion, I want to emphasize that companies need people at all stages of adult development if they want to function effectively (Dalton, et al., 1977). It is possible to mesh the needs of the company and of the individuals who work for it, provided management, particularly personnel management, is willing to work hard enough at it.

Davis and Gould made the point that managers of large corporations commonly look at their companies as portfolios of businesses. Businesses are arrayed according to various points in a business life cycle and resources are then allocated accordingly. They went on to argue that, just as it is inappropriate to regard all businesses as the same, it is inappropriate to ignore differences between managers at different stages of their lives. It is necessary to mesh the strategic planning of the organization with the skills, personalities and phases of growth of the available executives. On the individual side, the way in which a manager behaves should be seen as 'meaningful to the tasks of the particular period in life he is in' (Davis, 1981:130). 'Management could also match the kind of manager called for in a particular assignment with the expected and appropriate behavior of people at different points in their lives'.

I realize fully that this is a somewhat utopian view, applicable more to very large organizations than the smallish ones with which most of us are more familiar. I also know that the combination of a narrowing hierarchical funnel and the increasing age of a fair number of managers does not always allow for such meshing in the case of all of them. Perhaps we need to learn some lessons from the Japanese on how to employ people life-long. Yet there seems to be no reason why this approach should be ignored - it could be applied as often as possible and wherever appropriate, to the benefit of both individuals and the work organizations to whom they are, after 
all, giving the major portion of their lives.

\section{References}

Alexander, C.P. 1983. The new economy. Time. 30 May, pp.68-76.

Argote, L. Goodman, P.S., \& Schkade, D. 1983. The human side of robotics: How workers react to a robot. Sloan Manage. Rev. vol. 24: $31-41$.

Bartolomé, F. 1983. The work alibi: When it's harder to go home. Harv. Bus. Rev. vol. 61 (2):67-74.

Bowen, D.D. \& Hall, D.T. 1977. Career planning for employee development: A primer for management. Calif. Manage. Rev. vol. $20(2): 23-35$

Constandse, W.J. 1972. A neglected personnel problem. Pers. J. vol. 51; $129-133$.

Dalton, G.W., Thompson, P.H. \& Price, R.L. 1977. The four stages of professional careers: A new look at performance by professionals. Organ. Dyn. vol. $6(1): 19-42$.

Davis, S.M. \& Gould, R.L. 1981. Three vice presidents in mid-life. Harv. Bus. Rev. vol. 59 (4):118-130.

Dawson, C.M. 1983. Will career plateauing become a bigger problem? Pers. J. vol. 62 (1): $78-81$

De Charms, R. 1968. Personal causation: The internal affective determinants of behavior. New York: Academic Press.

Dods, R.A. 1980. Is there a sabbatical in your future? How one senior business partner planned his. Bus. $Q$. vol. 45 (4):30- 36 .

Erikson, E.H. 1963. Childhood and society (Rev, ed.). New York: Norion.

Erikson, E.H. (Ed.) 1978. Adulthood. New York: Norton.

Gould, R.L. 1978. Transformations: Growth and change in adult life. New York: Simon \& Schuster.

Hall, D.J. 1976. Careers in organizations. Pacific Palisades, Calif.: Goodyear.

Houle, C.O. 1980. Continuing learning in the professions. San Francisco: Jossey-Bass.

HSSE Newsletter (Special Library Issue). 1983. School of Humanities, Social Science, and Education, Purdue University, West Lafayette, Ind.

Isaacson, L.E. 1981. Counseling male midlife career changes. Vocational Guidance $Q$. vol. 24:324-331.
Jaques, E. 1965. Death and the mid-life crisis. Int. J. of Psycho. vol. $46: 502-514$

Kellerman, A.M. 1983. Pioneer and traditional working women. Unpublished D.Phil. thesis, University of Port Elizabeth.

Kets de Vries, M.F.R. 1978. The midcareer conundrum. Organ. Dyn vol. $7(2): 45-62$.

Lathem, E.C. (Ed.). 1969. The poetry of Robert Frost. New York: Holt, Rinehart \& Winston.

Lawrence, B.S. 1980. The myth of the midlife crisis. Sloan Manage. Rev. vol. $21: 35-49$.

Levinson, D.J., Darrow, C.N., Klein, E.B., Levinson, M.H. \& McKee, B. 1978. The seasons of a man's life. New York: Knopf.

Levinson, H. 1983. A second career: the possible dream. Harv. Bus. Rev. vol. 61: (3), $122-129$.

McConkey, D. \& Barrett, F.D. 1982. Managing in the age of the robot. Bus. $Q$. vol. 47 (4): $40-46$.

Mead, M. 1972. The future: Prefigurative cultures and unknown children. In A. Toffler (Ed.), The futurists. New York: Random House.

Saga, I. 1983. Japan's robots produce problems for workers. Wall Street $J .28$ February, p. 21.

Schein, E.H. 1978. Career dynamics: Matching individual and organizational needs. Reading, Mass.: Addison-Wesley.

Shakespeare, W. Julius Ceasar, IV, 3, 218-221.

Sherwood, J.J. \& Glidewell, J.C. 1975. Planned renegotiation: A normsetting OD intervention. In W.W. Burke (Ed.), New technologies in organization development: 1. La Jolla, Calif: University Associates.

Souerwine, A.H. 1977. A mythology of career growth. Manage. Rev. June, $55-60$.

Taylor, A.L. 1982. Dealing with terminal phobia. Time, 19 July, p.74.

The Woodlands Group. 1980. Management development roles: Coach, sponsor and mentor. Pers. J. vol. 59:918-921.

Van Rooyen, J. 1981. Female career commitment. CSIR Special Report PERS 327. Johannesburg.

Wyndham, C.H. 1978. Ischaemic heart disease mortality rates in White South Africans compared to other populations. S. Afr. Med. J. vol. 54:595-601. 